\title{
GOVERNMENT AND POLITICS IN AFRICA
}


Also by William Tordoff

ASHANTI UNDER THE PREMPEHS, 1888-1935

GOVERNMENT AND POLITICS IN TANZANIA

POLITICS IN ZAMBIA (editor and co-author)

ADMINISTRATION IN ZAMBIA (editor and co-author)

THIRD WORLD POLITICS: A Comparative Introduction (with Paul

Cammack and David Pool)

VOTES AND BUDGETS: Comparative Studies in Accountable

Governance in the South (co-editor with John Healey) 


\section{GOVERNMENT AND POLITICS IN AFRICA}

ThiRd EDITION

WILLIAM TORDOFF

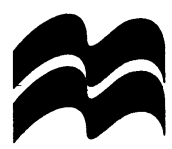




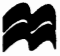

(C) William Tordoff, 1984, 1993, 1997

All rights reserved. No reproduction, copy or transmission of this publication may be made without written permission.

No paragraph of this publication may be reproduced, copied or transmitted save with written permission or in accordance with the provisions of the Copyright, Designs and Patents Act 1988, or under the terms of any licence permitting limited copying issued by the Copyright Licensing Agency, 90 Tottenham Court Road, London W1P 9HE.

Any person who does any unauthorised act in relation to this publication may be liable to criminal prosecution and civil claims for damages.

The author has asserted his right to be identified as the author of this work in accordance with the Copyright, Designs and Patents Act 1988.

First edition 1984, reprinted five times

Second edition 1993, reprinted three times

Third edition 1997

Published by

MACMILLAN PRESS LTD

Houndmills, Basingstoke, Hampshire RG21 6XS

and London

Companies and representatives

throughout the world

ISBN 978-0-333-69474-9

DOI 10.1007/978-1-349-25789-8

ISBN 978-1-349-25789-8 (eBook)

A catalogue record for this book is available from the British Library.

This book is printed on paper suitable for recycling and made from fully managed and sustained forest sources.

$\begin{array}{rrrrrrrrrr}10 & 9 & 8 & 7 & 6 & 5 & 4 & 3 & 2 & 1 \\ 06 & 05 & 04 & 03 & 02 & 01 & 00 & 99 & 98 & 97\end{array}$

Copy-edited and typeset by Povey-Edmondson Tavistock and Rochdale, England 
For

Vanessa and Luke

Alice and Nicole 


\section{Contents}

Preface and Acknowledgements viii

Abbreviations and Acronyms $\mathrm{x}$

Changes in Country Names $\quad \mathrm{xv}$

Political Map of Africa xviii

Table: Basic Indicators $\quad$ xx

1 Introduction: African Politics since Independence 1

2 Colonialism and the Colonial Impact 28

3 Nationalism and the Transfer of Power 47

4 State and Society 82

5 Political Parties 113

6 Administration 145

7 The Military 180

8 Revolutionary Movements and Former Revolutionary Regimes 209

9 Regional Groupings and the Organisation of African Unity 260

10 Conclusions: Ideology, the Post-Colonial State and Development 289

Notes and References $\quad 327$

$\begin{array}{ll}\text { Index } & 369\end{array}$ 


\section{Preface and Acknowledgements}

I decided initially to take the end of 1995 as the cut-off date for this third edition of Government and Politics in Africa. However, as fresh events unfolded in 1996 I extended this date selectively to cover important incidents, such as Mathieu Kérékou's return to power in Benin following his success in the presidential election in March and the National Party's withdrawal from South Africa's ruling coalition government in June.

This expanded edition includes new material on the decline and weakness of the state, leading to the emergence in some countries for example, Liberia and Sierra Leone - to what William Reno has called the 'shadow state'. The state's relation to society is discussed further and the importance of ethnicity as a determinant of political behaviour - notably in the Rwandan context - is assessed. More attention is given to the position of women, who, in the postindependence period, have failed to secure rewards commensurate with their contribution to the independence struggle. The extent to which power is decentralised to provincial and district levels is examined, as is the establishment of black majority rule in South Africa and its significance for African states to the north. Economic reform measures and political liberalisation initiatives are subject to fresh analysis, though the main conclusions which I reached in the second edition remain unchanged. These are firstly that experiments in private enterprise are unlikely to be successful unless the institutional structure that the market economy requires is strengthened and that in the meantime the economic role of the state will remain important; and secondly, that while Africa's objective circumstances do not exclude political democracy, they are generally unfavourable to its early achievement and continuance.

As before, the help and advice which I have received from Ralph A. Young of the Department of Government, University of Manchester, have been invaluable and are greatly appreciated. I am 
grateful to my publisher Steven Kennedy and to Keith Povey and Gail Sheffield for their guidance in preparing this edition for publication, and especially to my wife Audrey for her constant support and for freeing me from many of the tasks of everyday life.

I am indebted to the Director of the Publications Department, World Bank, Washington, DC, for allowing me to reproduce in an amended form at pp. $\mathrm{xx}$-xxii the tables, 'Table 1 and Table 1a. Basic Indicators', which appear in Workers in an Integrating World: World Development Report, 1995 (published for the World Bank by Oxford University Press, 1995), pp. 162-3 and 228.

I wish to thank also Christopher Pycroft of the University of Liverpool for making available to me, and allowing me to make use of, his informative paper 'Local Government in the New South Africa' (LIPAM, University of Liverpool, mimeo, February 1996). 


\section{Abbreviations and Acronyms}

Note: Where the geographic locus of any organisation is not clear from its title, this has been indicated in brackets.

$\begin{array}{ll}\text { AAPC } & \text { All-African People's Conference } \\ \text { ACP } & \text { African-Caribbean-Pacific (countries) } \\ \text { AEF } & \text { Afrique Equatoriale Française } \\ \text { AFORD } & \text { Alliance for Democracy [Malawi] } \\ \text { AFRC } & \text { Armed Forces Revolutionary Council [Ghana] } \\ \text { AG } & \text { Action Group [Nigeria] } \\ \text { ALC } & \text { African Liberation Committee } \\ \text { AMU } & \text { African Mineworkers' Union [Northern Rhodesia/ } \\ & \text { Zambia] } \\ \text { ANC } & \text { African National Congress [Northern Rhodesia/Zambia; } \\ & \text { South Africa] } \\ \text { AOF } & \text { Afrique Occidentale Française } \\ \text { APC } & \text { All People's Congress [Sierra Leone] } \\ \text { ARDP } & \text { Accelerated Rural Development Programme [Botswana] } \\ \text { ARPS } & \text { Aborgines' Rights Protection Society [Gold Coast] } \\ \text { ASP } & \text { Afro-Shirazi Party [Zanzibar] } \\ \text { BDP } & \text { Botswana Democratic Party } \\ \text { BNF } & \text { Botswana National Front } \\ \text { BPN } & \text { Bureau Politique Nationale [Guinea] } \\ \text { CCM } & \text { Chama cha Mapinduzi [Tanzania] } \\ \text { CDR } & \text { Committee of the Defence of the Revolution [Burkina } \\ \text { CEAO } & \text { Faso] } \\ \text { CEEAC } & \text { Communauté Economique de l'Afrique de l'Ouest } \\ \text { CFA } & \text { Communaute Economique des Etats de l'Afrique } \\ \text { CFAO } & \text { Centrale } \\ \text { CIAS } & \text { Central Franc Afrique } \\ \text { CNR } & \text { Compagnie Française de l'Afrique Occidentale } \\ \text { COMESA } & \text { Conference of Independent African States } \\ \text { COREMO } & \text { Conseil National de la Révolution [Burkina Faso] } \\ \text { COSATU } & \text { Common Market for Eastern and Southern Africa } \\ \text { CPP } & \text { Comite Revolucionário de Moçambique } \\ \text { CPO } & \text { Congress of South African Trade Unions } \\ \text { CPR } & \text { Convention People's Party [Gold Coast/Ghana] } \\ \text { CTRN } & \text { Central Planning Officer [Botswana] } \\ \text { CUF } & \text { Council of People's Representatives [Ethiopia] } \\ & \text { Transitional Committee of National Recovery [Guinea] } \\ & \text { Companhia União Fabril [Portugal] } \\ & \end{array}$




\begin{tabular}{|c|c|}
\hline DC & District Development Committee [Botswana et al.] \\
\hline DDCC & District Development Coordinating Committee [Zambia] \\
\hline DIAMANG & Angolan Diamond Company \\
\hline DO(D) & District Officer (Development) [Botswana] \\
\hline DTA & Democratic Turnhalle Alliance [Namibia] \\
\hline EAC & East African Community \\
\hline EACSO & East African Common Services Organisation \\
\hline ECA & Economic Commission for Africa [United Nations] \\
\hline ECOMOG & ECOWAS Monitoring Group \\
\hline ECOWAS & Economic Community of West African States \\
\hline EEC & European Economic Community \\
\hline EPLF & Eritrea People's Liberation Front \\
\hline EPRDF & Ethiopian People's Revolutionary Democratic Front \\
\hline EPRP & Ethiopian People's Revolutionary Party \\
\hline ERP & Economic Recovery Programme [Ghana et al.] \\
\hline EU & European Union \\
\hline F. \& C.O. & Foreign and Commonwealth Office \\
\hline FDD & Forces for the Defence of Democracy (Burundi) \\
\hline FIS & Front Islamique de Salut [Algeria] \\
\hline FLING & $\begin{array}{l}\text { Frente para a Libertação e Independência da Guiné } \\
\text { Portuguesa }\end{array}$ \\
\hline FLN & Front de Libération Nationale [Algeria] \\
\hline FLS & Front-Line States \\
\hline FNLA & Frente Nacional de Libertaçao de Angola \\
\hline FRELIMO & Frente de Libertação de Moçambique \\
\hline GDP & Gross Domestic Product \\
\hline GIA & Groupe Islamique Armée [Algeria] \\
\hline GNP & Gross National Product \\
\hline IMF & International Monetary Fund \\
\hline IFP & Inkatha Freedom Party \\
\hline KADU & Kenya African Democratic Union \\
\hline KANU & Kenya African National Union \\
\hline KFL & Kenya Federation of Labour \\
\hline KPU & Kenya People's Union \\
\hline LDC & Less-Developed Country \\
\hline LGNF & Local Government Negotiating Forum [South Africa] \\
\hline LOGOSP & Local Government Support Project [Zambia] \\
\hline MAP & Muslim Association Party [Gold Coast/Ghana] \\
\hline MCP & Malawi Congress Party \\
\hline MFDP & $\begin{array}{l}\text { Ministry of Finance and Development Planning } \\
\text { [Botswana] }\end{array}$ \\
\hline MINURSO & $\begin{array}{l}\text { Mission for the Referendum in Western Somalia [United } \\
\text { Nations] }\end{array}$ \\
\hline MLGH & Ministry of Local Government and Housing [Zambia] \\
\hline MLGL & Ministry of Local Government and Lands [Botswana] \\
\hline MMD & Movement for Multi-Party Democracy [Zambia] \\
\hline MNC & Multinational Corporation \\
\hline MPD & Movement for Democracy Party [Cape Verde] \\
\hline MPLA & Movimento Popular de Libertação de Angola \\
\hline
\end{tabular}




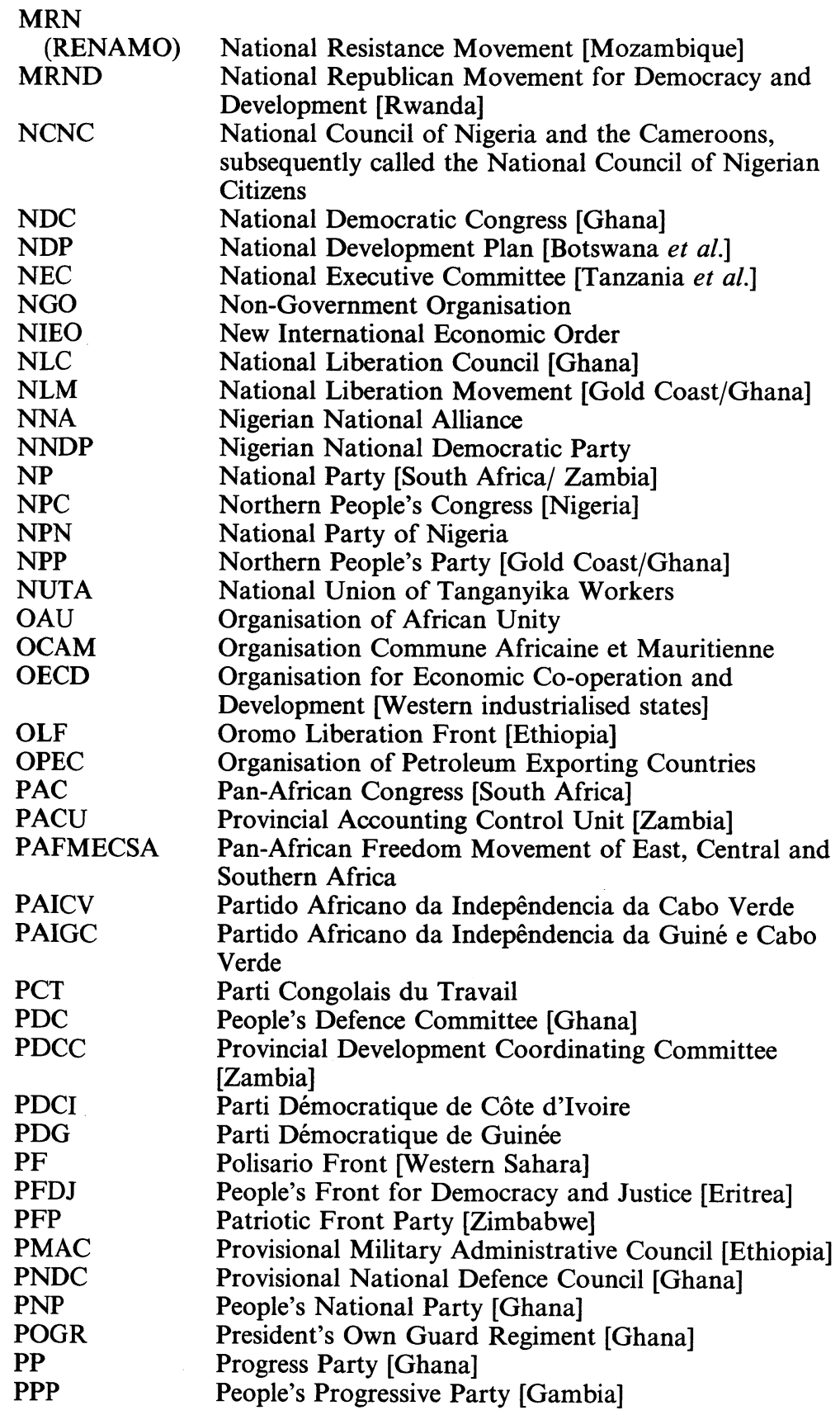




\begin{tabular}{|c|c|}
\hline PPN & Parti Progressiste Nigérien \\
\hline PRA & Parti de Regroupement Africain [French Black Africa] \\
\hline PRL & Pouvoir Révolutionnaire Locale [Guinea] \\
\hline PRP & $\begin{array}{l}\text { People's Redemption Party [Nigeria]; People's } \\
\text { Revolutionary Party [Benin] }\end{array}$ \\
\hline PS & Parti Socialiste [Senegal] \\
\hline PTA & Preferential Trade Area [Southern Africa] \\
\hline PUP & Party of Unity and Progress [Guinea] \\
\hline RCD & Rassemblement Constitutional Démocratique [Tunisia] \\
\hline RDA & Rassemblement Démocratique Africain [French Africa] \\
\hline RDP & $\begin{array}{l}\text { Reconstruction and Development Programme [South } \\
\text { Africa] }\end{array}$ \\
\hline RENAMO & See MRN \\
\hline RPF & Rwandan Patriotic Front \\
\hline RPT & Rassemblement du Peuple Togolaise \\
\hline RUF & Revolutionary United Front [Sierra Leone] \\
\hline SACP & South African Communist Party \\
\hline SACU & South African Customs Union \\
\hline SADC & Southern African Development Community \\
\hline SADCC & $\begin{array}{l}\text { Southern African Development Co-ordination } \\
\text { Conference }\end{array}$ \\
\hline SADR & Saharan/Sahrawi Arab Democratic Republic \\
\hline SAP & Structural Adjustment Programme \\
\hline SCOA & Société Commerciale de l'Ouest Africain \\
\hline SDP & Social Democratic Party [Nigeria] \\
\hline SLPP & Sierra Leone People's Party \\
\hline SMC & Supreme Military Council [Nigeria] \\
\hline SNM & Somali National Movement \\
\hline SPLA & Sudanese People's Liberation Army \\
\hline SPM & Somali Patriotic Movement \\
\hline SRC & Supreme Revolutionary Council [Somalia] \\
\hline SRSP & Somali Revolutionary Socialist Party \\
\hline SSLM & Southern Sudan Liberation Movement \\
\hline SWAPO & South West African People's Organisation \\
\hline TANU & Tanganyika African National Union \\
\hline TCP & Togoland Congress Party [Gold Coast/Ghana] \\
\hline TDC & Transitional District Council [South Africa] \\
\hline TFFTU & Tanzania Federation of Free Trade Unions \\
\hline TFL & Tanganyika Federation of Labour \\
\hline TLC & Transitional Local Council [South Africa] \\
\hline TPLF & Tigray People's Liberation Front [Ethiopia] \\
\hline TRC & Transitional Representative Council [South Africa] \\
\hline TUC & Trades Union Congress [Ghana et al.] \\
\hline UAC & United Africa Company [Britain] \\
\hline UAM & Union Africaine et Malgache \\
\hline UDEAC & Union Douanière et Economique de l'Afrique Centrale \\
\hline UDF & United Democratic Front [Malawi] \\
\hline UDPM & Union Démocratique du Peuple Malien \\
\hline UDV & Union Démocratique Voltaique \\
\hline
\end{tabular}




$\begin{array}{ll}\text { UFIR } & \text { Union of Federalists and Independent Republicans } \\ \text { UGCC } & \text { [Zaire] } \\ \text { UGTAN } & \text { United Gold Coast Convention } \\ & \text { [Guinea] } \\ \text { UN } & \text { United Nations } \\ \text { UNAVEM III } & \text { United Nations Angola Verification Mission } \\ \text { UNCTAD } & \text { United Nations Conference on Trade and Development } \\ \text { UNIP } & \text { United National Independence Party [Northern } \\ & \text { Rhodesia/Zambia] } \\ \text { UNITA } & \text { União Nacional para a Independência Total de Angola } \\ \text { UNOMIL } & \text { United Nations Observer Mission to Liberia } \\ \text { UNOSOM II } & \text { United Nations Operation in Somalia } \\ \text { UPADS } & \text { Union Pan-Africain pour la Démocratie Sociale [Congo] } \\ \text { UPC } & \text { Uganda People's Congress } \\ \text { UPGA } & \text { United Progressive Grand Alliance [Nigeria] } \\ \text { UPN } & \text { Unity Party of Nigeria } \\ \text { UPP } & \text { United Progressive Party [Zambia] } \\ \text { UPS } & \text { Union Progressiste Sénégalaise } \\ \text { US } & \text { Union Soudanaise [French Soudan/Mali] } \\ \text { USAID } & \text { United States Agency for International Development } \\ \text { USC } & \text { United Somali Congress } \\ \text { UWUSA } & \text { United Workers' Union of South Africa } \\ \text { WDC } & \text { Workers' Defence Committee [Ghana] } \\ \text { WPE } & \text { Workers'Party of Ethiopia } \\ \text { WSLF } & \text { Western Somalia Liberation Front } \\ \text { ZANLA } & \text { Zimbabwe African National Liberation Army } \\ \text { ZANU } & \text { Zimbabwe African National Union } \\ \text { ZANU-PF } & \text { Zimbabwe African National Union (Patriotic Front) } \\ \text { ZAPU } & \text { Zimbabwe African People's Union } \\ \text { ZIMCO } & \text { Zambia Industrial and Mining Corporation } \\ \text { ZIPRA } & \text { Zimbabwe People's Revolutionary Army } \\ \text { ZUM } & \text { Zimbabwe Unity Movement } \\ & \end{array}$




\section{Changes in Country Names}

Note. Throughout the text, I have used the name by which the country was known at the date relevant to the discussion. Changes of name usually occurred at independence; post-independence changes are indicated in brackets.

Present

Benin (1975)

Botswana

Burundi $^{1}$

Cameroon

Cape Verde

Central African Republic

Congo

Djibouti

Equatorial Guinea

Eritrea

Gambia/Senegambia ${ }^{6}$

Ghana

Guinea-Bissau

Cote d'Ivoire $^{7}$

Lesotho

Malagasy Republic/

Madagascar

Malawi

Mali $^{8}$

Namibia

Rwanda $^{1}$

Saharan Arab Democratic

Republic $^{9}$

Senegal/Senegambia ${ }^{6}$
Pre-independence

Dahomey

Bechuanaland

Ruanda-Urundi

SFrench Cameroons

British Southern Cameroons ${ }^{2}$

Cape Verde Islands

Oubangui Chari

French Congo ${ }^{3}$

French Territory of the Afars and Issas ${ }^{4}$

Spanish Guinea

Eritrea, within Ethiopia ${ }^{5}$

Gambia

Gold Coast and British

Togoland

Portuguese Guinea

Ivory Coast

Basutoland

Madagascar

Nyasaland

French Soudan

South West Africa

Ruanda-Urundi

Spanish Sahara/Western

Sahara

Senegal 
Present

Somalia/Somali Democratic

Republic

Somaliland ${ }^{10}$

South Africa

(black majority rule) $^{11}$

Tanzania (1965) ${ }^{12}$

Togo

Zaire (1971)

Zambia

Zimbabwe
Pre-independence

SBritish Somaliland

Italian Somaliland

northern region of Somalia

South Africa

(white minority rule)

\{ Tanganyika

Zanzibar

French Togoland

Belgian Congo ${ }^{13}$

Northern Rhodesia

Southern Rhodesia/Rhodesia

Notes

1. Ruanda-Urundi was a Belgian-administered UN trust territory which became independent in 1960 as two separate states, Rwanda and Burundi.

2. The Southern Cameroons, a British-administered UN trust territory, joined the Republic of Cameroon following a plebiscite in 1961; the people of the Northern Cameroons opted for integration with Nigeria.

3. Often referred to as Congo-Brazzaville.

4. Often referred to as French Somaliland.

5. Eritrea was subject in turn to Italian colonial rule, British military administration, and Ethiopian control. The imperial regime's destruction of Eritrean autonomy after 1952 provoked armed guerilla opposition that ended with the achievement of independence in 1993.

6. The names 'Gambia' and 'Senegal' are retained. In 1981 the two states formed the confederation of Senegambia; this was dissolved in 1989.

7. In 1986 the Ivorian government instructed international organisations to use the French language designation in all official documents. I have used this designation to cover the period from 1986.

8. The Mali Federation was formed by Senegal and Soudan in 1959, but survived for less than three months after being granted political independence by France in June 1960. France then recognised the separate independence of Senegal and Soudan, and the Union Soudanaise changed the name of Soudan to the Republic of Mali. 
9. Also known as the Sahrawi Arab Democratic Republic. Its international status is still in dispute.

10. The northern region of Somalia declared itself independent as the Republic of Somaliland in 1991; the United Nations has not yet granted recognition.

11. No change in name, but a change in substance of immense importance occurred when non-racial multi-party elections in April 1994 resulted in the establishment of black majority rule.

12. The United Republic of Tanganyika and Zanzibar came into being on 26 April 1964, as a consequence of the union between Tanganyika and Zanzibar; the name 'United Republic of Tanzania' was officially adopted a year later.

13. Often referred to as Congo-Léopoldville and subsequently (from 1 July 1966) as Congo-Kinshasa. 


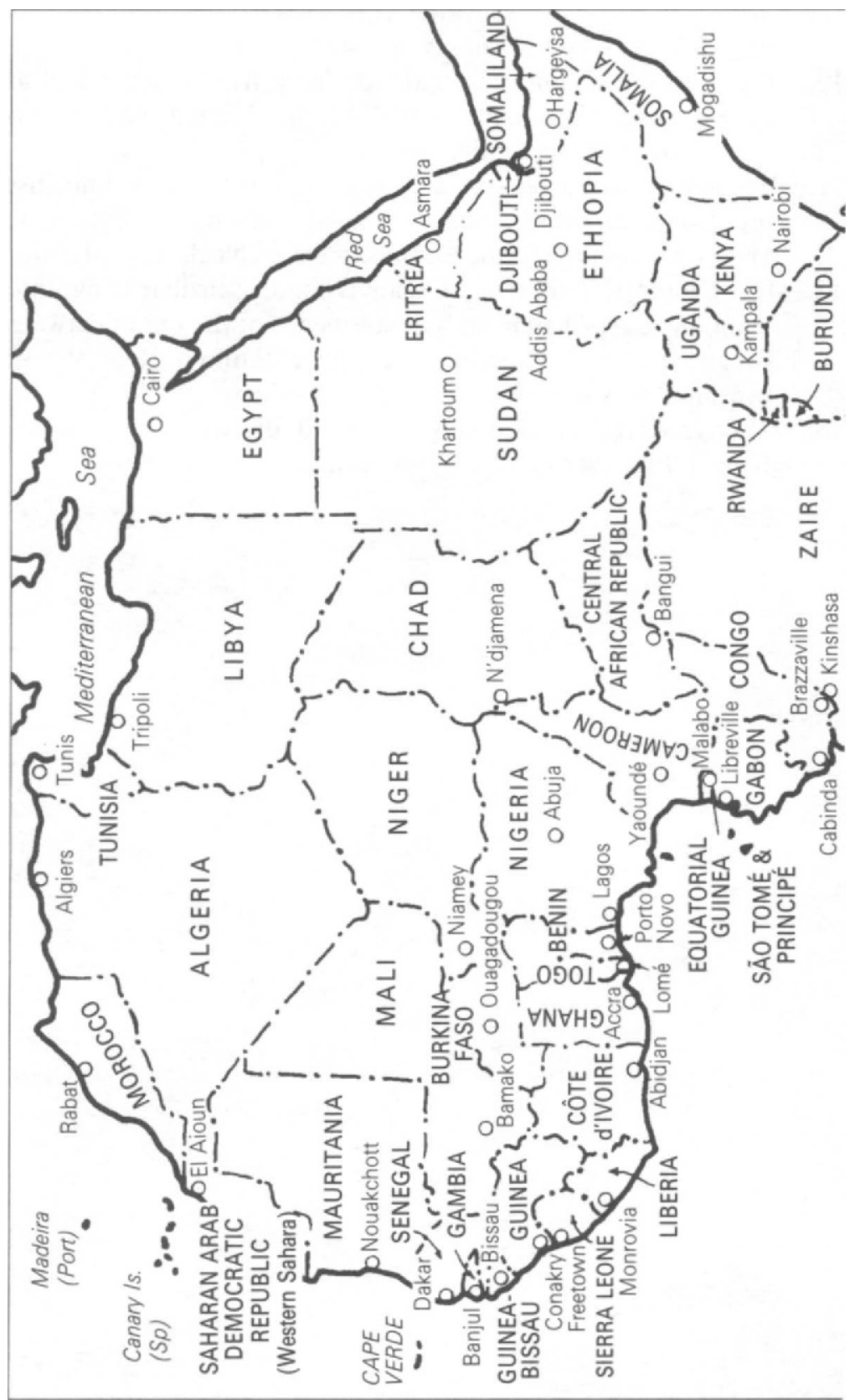




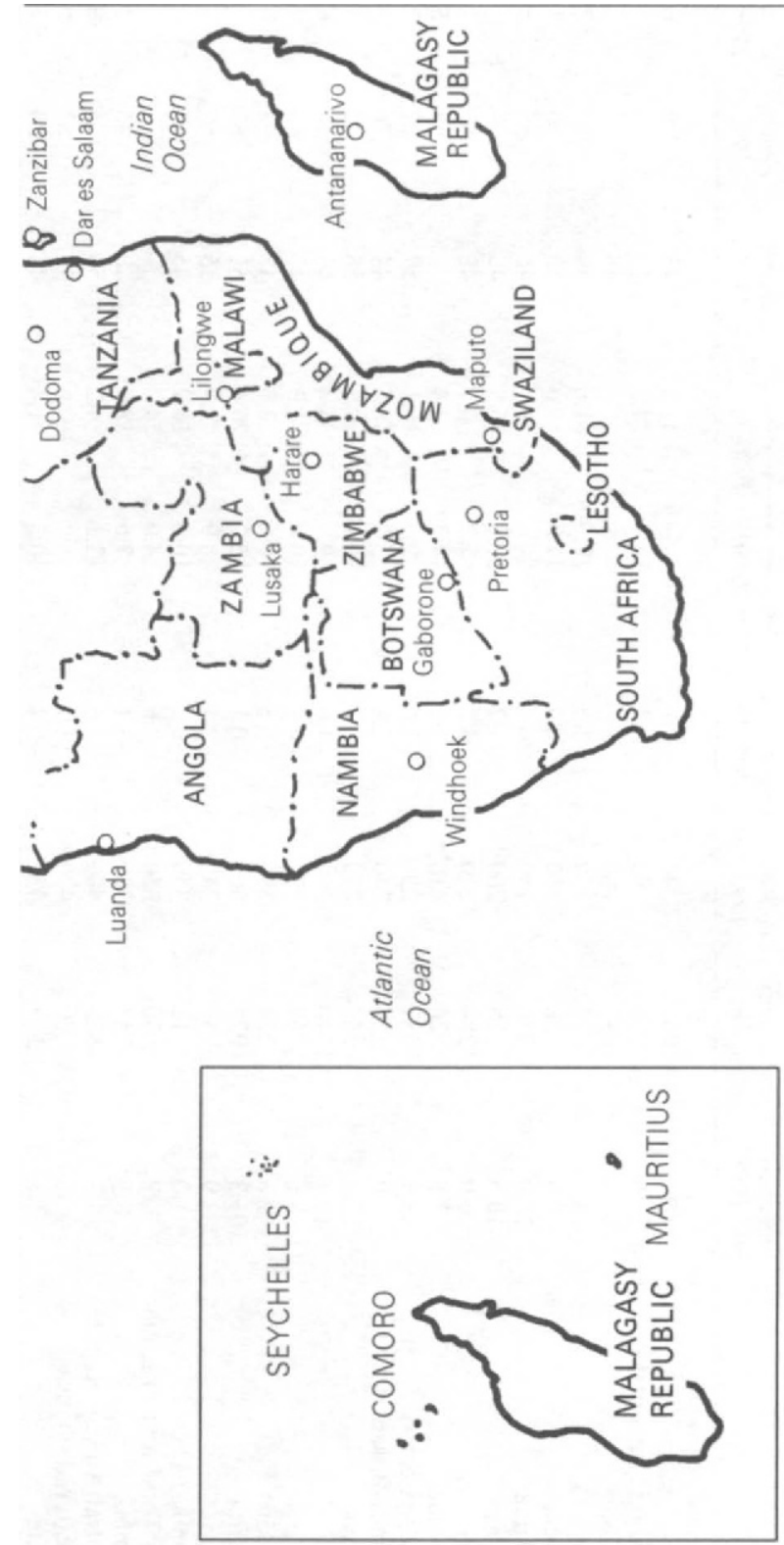

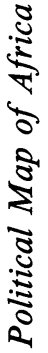




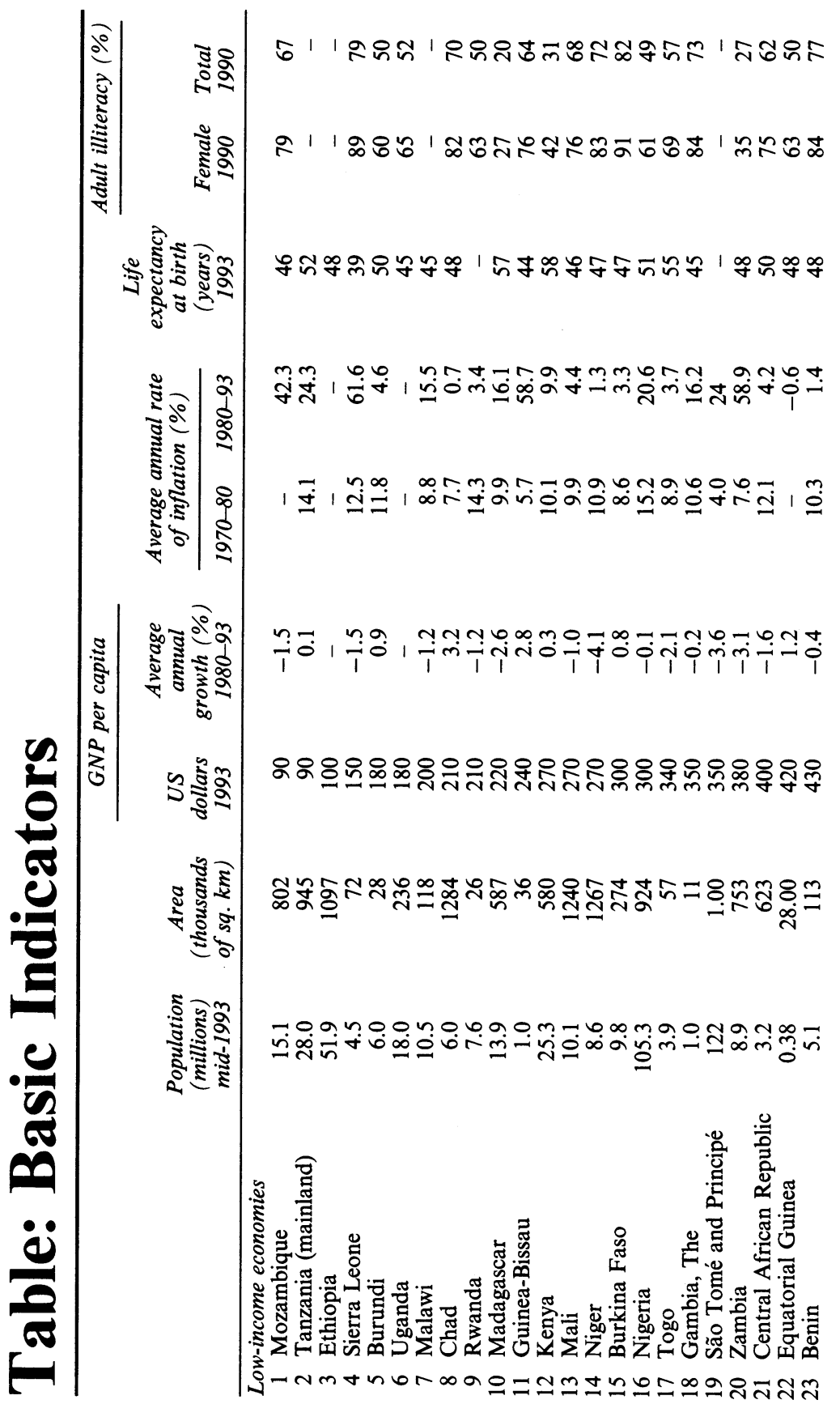




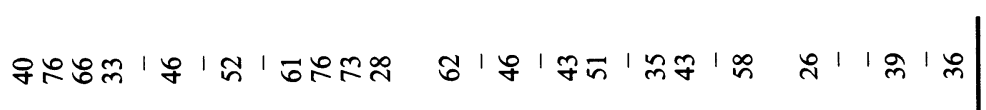

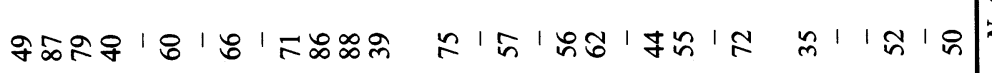

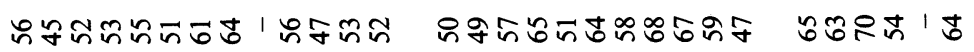
官

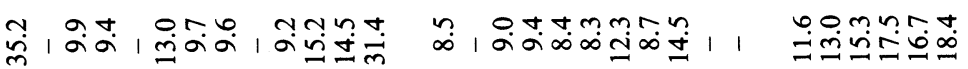
官 |

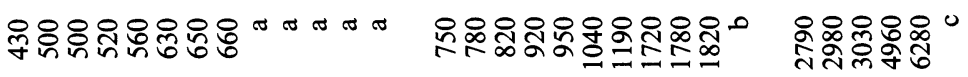

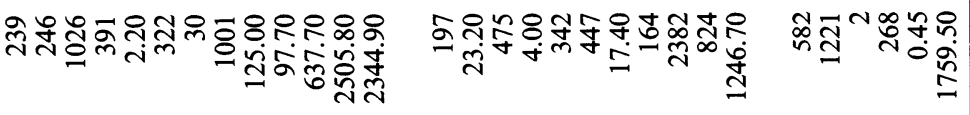

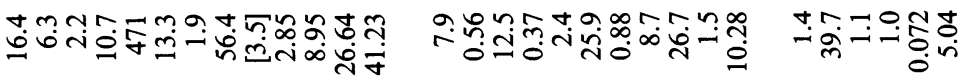

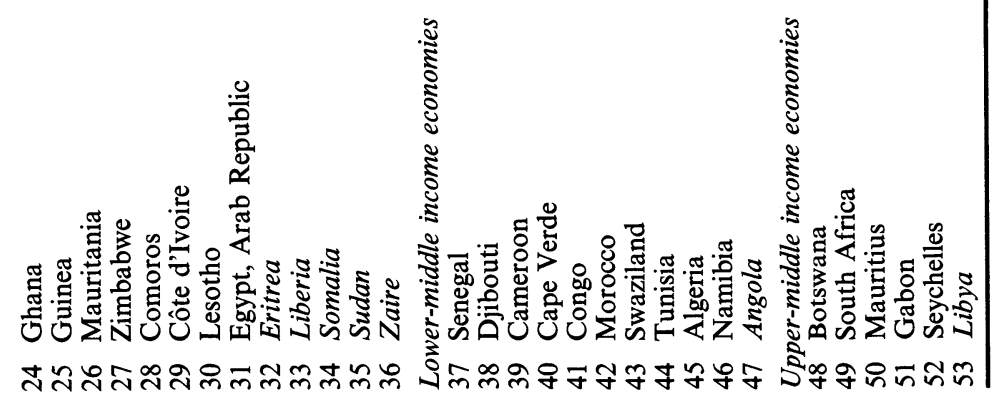


Notes:

(1) The main criterion used to classify African state economies (in ascending order) is GNP; however, it should be remembered that classification by income does not necessarily reflect development status.

(2) The summary measures for GNP per capita, life expectancy, and adult (i.e. 15 years plus) illiteracy are weighted by population. Those for average annual rates of inflation are weighted by the 1987 share of country GDP valued in current US dollars.

(3) Countries in italics have data for years other than those specified.

$\mathrm{a}=$ estimated to be low-income (US\$695 or less)

$\mathrm{b}=$ estimated to be lower-middle income (\$696 to $\$ 2785$ )

$c=$ estimated to be upper-middle income ( $\$ 2786$ to $\$ 8625)$ : the 1993 GNP per capita for Botswana has recently been revised from $\$ 2590$ to $\$ 2790$. For convenience, I have grouped those countries (some wracked with civil war) where no GNP figures were available at the end of the relevant division. However, if such information was to hand, a number of them would be placed higher in the relevant band; thus Eritrea, one of Africa's poorest countries, would be listed near the top of band a.

Source: Adapted from Workers in an Integrating World: World Development Report, 1995 (published for the World Bank by Oxford University Press, 1995), Table 1, pp. 162-3, and Table 1a, p. 228. 